\title{
GERAKAN 1000 HARI PERTAMA KEHIDUPAN MENCEGAH TERJADINYA STUNTING PADA ANAK USIA 0-59 BULAN DI KABUPATEN DHARMASRAYA
}

\section{THE FIRST 1000 DAYS OF LIFE MOVEMENT PREVENTS STUNTING IN CHILDREN AGED 0-59 MONTHS IN DHARMASRAYA DISTRICT}

\author{
Ningsih saputri ${ }^{\bowtie 1}$, Husna $^{2}$ \\ Universitas Dharmas Indonesia, Sumatra Barat. Indonesia \\ Correspondence Email: ningsihsaputri378@gmail.com
}

\begin{abstract}
ABSTRAK
Stunting merupakan salah satu indikator masalah gizi yang menjadi fokus Global Scaling Up Nutrition (SUN) Movement pada 1000 Hari Pertama Kehidupan (HPK) Jumlah status gizi di Indonesia yang mengalami Stunting pada tahun 2007 sekitar 36,8\%, tahun 2013 mengalami kenaikan sekitar 37, 2\%, pada tahun 2018 mengalami penurunan sekitar 30,8\% tetapi tidak mengalami penurunan yang signifikan. Tujuan penelitian ini yaitu untuk melihat Gerakan 1000 HPK mencegah terjadinya stunting pada anak usia 0-59 bulan. Metode penelitian ini menggunakan kuantitatif dengan desain case control dan tekhnik pengambilan sampel purposive sampling. Penelitian ini dilaksanakan bulan Juni-Juli di Puskesmas Sitiung I Kabupaten Dharmasraya. Analisa penelitian dilakukan dengan uji chi square. Hasil menunjukkan hubungan dalam kejadian stunting adalah konsumsi tablet FE dengan $p_{-}$value 0,003, Asi Eksklusif dengan $p_{-}$value 0,020, MP-ASI dengan $p_{-}$value 0,020 , pola asuh dengan $p_{-}$value 0,000 .
\end{abstract}

Kata kunci: stunting; konsumsi tablet Fe; anak usia 0-59 bulan

\begin{abstract}
Stunting is one indicator of nutritional problems that is the focus of the Global Scaling up Nutrition (SUN) Movement in the First 1000 Days of Life (HPK). in 2018 experienced a decrease of around 30.8\% but did not experience a significant decrease. The purpose of this study was to observe the 1000 HPK Movement to prevent stunting in children aged 0-59 months. This research method uses quantitative with case control design and purposive sampling technique. This research was conducted in June-July at Sitiung I District Health Center, Dharmasraya Regency. The research analysis was carried out by using the chi square test. The results showed that the relationship in the incidence of stunting was the consumption of FE tablets with a p_value of 0.003 , exclusive breastfeeding with a $p_{-}$value of 0.020 , complementary feeding with a $p_{-}$value of 0.020 , parenting with a p_value of 0.000 .
\end{abstract}

Keywords: stunting; consumption of Fe tablets; children aged 0-59 months 


\section{PENDAHULUAN}

Periode 1000 hari pertama kehidupan dihitung dari sejak pertama hari kehamilan, kelahiran bayi sampai anak usia 2 tahun yaitu 270 hari selama kehamilan dan 730 hari pada kehidupan pertama bayi yang dilahirkan (Menteri koordinator bidang kesejahteraan rakyat, 2013). Periode 1000 hari adalah periode emas yang dimulai sejak saat konsepsi, pertumbuhan janin dalam rahim, hingga ulang tahun ke 2 kehidupannya,yang akan menentukan kualitas kesehatan pada kehidupan selanjutnya (Fakultas Kedokteran Universitas Hasanudin, 2014).

Stunting merupakan salah satu indikator masalah gizi yang menjadi fokus Global Scaling Up Nutrition (SUN) Movement pada 1000 Hari Pertama Kehidupan (HPK). Selain Stunting, Indonesia juga menghadapi masalah gizi lainnya yaitu berat badan lahir rendah (BBLR), kurus (wasting), gizi kurang (underweight), dan gizi lebih (overweight). Stunting atau anak pendek merupakan salah satu indikator dalam status gizi kronis yang menggambarkan terhambatnya pertumbuhan karena malnutrisi jangka panjang (BAPPENAS, 2012). Menurut WHO prevalensi Stunting menjadi masalah kesehatan masyarakat jika prevalensinya lebih dari 20 persen. Jumlah status gizi di Indonesia yang mengalami Stunting pada tahun 2007 sekitar 36,8\% pada tahun 2013 mengalami kenaikan sekitar $37,2 \%$ dan pada tahun 2018 mengalami penurunan sekitar 30,8\% tetapi tidak mengalami penurunan yang signifikan. Hal ini mendapatkan perhatian yang lebih khusus untuk penanganannyaa. Kualitas kecukupan gizi belum memadai, tercermin dari prevalensi Stunting pada balita yang masih tinggi (Riskesdas, 2018).

Berdasarkan data PSG tahun 2015 di provinsi Sumatera Barat mencatat prevalensi Stunting sebesar 27,7\%, pada tahun 2016 prevalensi kejadian Stunting naik menjadi 29,0\% dan pada tahun 2017 naik lagi menjadi 29,6\%. Pada masing-masing Kota/Kabupaten di Provinsi Sumatera Barat sebagai berikut Pasaman 40,6\%, Solok 39,9\%, Sijunjung 38,7\%, Solok Selatan
$36,2 \%$, Padang Pariaman 33,6\%, Tanah Datar 33,0\%, Pasaman Barat 32,1\%, Kota Solok 31,9\%, Agam 31,1\%, Kota Padang Panjang 29,6\%, Kota Payakumbuh 28,0\%, Pesisir Selatan 27,5\%, Lima Puluh Kota 27,0\%, Dharmasraya 27,0\%, Kota Sawahlunto 26,3\%, Kota Pariaman 25,9\%, Kepulauan Mentawai 25,7\%, Kota Bukittinggi 24,5\%, Kota Padang 22,6\% (Hasil Pemantauan Status Gizi, 2016) (Hasil Pemantauan Status Gizi, 2017).

Hasil penelitian yang dilakukan oleh Teshale Fikadu dkk pada tahun 2014 dengan judul Faktor-Faktor Yang Terkait Dengan Pengerdilan Di Antara Anak-Anak Usia 24 Hingga 59 Bulan Di Distrik Meskan, Gurage Zone, South Ethiopia menunjukkan bahwa Ukuran keluarga, jumlah balita di rumah tangga, pekerjaan ibu, durasi pemberian ASI eksklusif, dan metode pemberian makanan pelengkap secara independen terkait dengan Stunting (Fikadu, Assegid, \& Dube, 2014).

Hasil penelitian yang dilakukan oleh Selamawit Bekele dkk pada tahun 2018 dengan judul Prevalensi Pengerdilan Dan Faktor-Faktor Terkait Di Antara Anak-Anak Usia 6-59 Bulan Di Distrik Libo-Kemekem, Ethiopia Barat Laut, Sebuah Studi Cross Sectional Berbasis Komunitas menunjukkan bahwa Stunting secara signifikan Berkorelasi dengan usia anak, status pekerjaan kepala rumah tangga, ukuran keluarga, dan Pendidikan ayah (Geberselassie, Abebe, Melsew, Mutuku, \& Wassie, 2018).

Hasil penelitian yang dilakukan oleh Ardian Candra M Dkk pada tahun 2016 dengan judul Determinan Kejadian Stunting Pada Bayi Usia 6 Bulan Di Kota Semarang menunjukkan bahwa Determinan yang tidak terbukti sebagai kejadian Stunting adalah pemberian ASI Eksklusif, pemberian MP ASI dini, alokasi waktu asuh ibu, tinggi badan ibu,lingkar kepala bayi. Sedangkan Determinan utama kejadian Stunting pada bayi usia 6 bulan adalah tingkat ekonomi rumah tangga (M, Subagio, \& Margawati, 2016).

Tujuan penelitian ini untuk melihat Gerakan 1000 HPK mencegah terjadinya stunting pada anak usia 0-59 bulan di Puskesmas Sitiung I Kabupaten Dharmasraya. 


\section{METODE}

Jenis penelitian yang dilakukan adalah kuantitatif yaitu melihat hubungan antara variabel independen (Konsumsi Tablet FE, BB bayi baru lahir, IMD, Asi Eksklusif, MP-ASI, Pola Asuh) dengan variabel dependen (kejadian stunting). Rancangan kuantitatif dalam penelitian ini menggunakan desain penelitian survey analitik dengan pendekatan case control, populasi

\section{HASIL}

Berdasarkan tabel 1. ditunjukkan pada kelompok kasus $12(70.6 \%)$ responden mengalami anemia sedangkan kelompok kontrol $26 \quad(76.5 \%)$ responden tidak mengalami anemia. Kelompok kasus terdapat $17(100 \%)$ responden lahir tidak dengan kondisi BBLR sedangkan pada kelompok kontrol terdapat 34 (100\%) responden lahir tidak dengan kondisi BBLR. Kelompok kasus 10 (58.8\%) responden tidak melakukan IMD dan kelompok kontrol $20 \quad(58.8 \%)$ responden penelitian ini adalah seluruh anak usia 0-59 bulan dan sampel penelitian adalah anak usia 0-59 bulan yang mengalami Stunting ( case ) dan anak yang tidak mengalami gangguan gizi apapun (kontrol) dengan jumlah sampel 51. Penelitian ini telah dilakukan pada bulan juni-juli tahun 2021 di Puskesmas Sitiung I. Pengambilan sampel dengan menggunakan purposive sampling.

melakukan IMD. Kelompok kasus 11 (64.7\%) responden tidak diberikan ASI Eksklusif dan kelompok kontrol $25(73.5 \%)$ responden di berikan ASI Eksklusif. Kelompok kasus terdapat 11 (64.7\%) responden tidak di berikan MP-ASI sedangkan pada kelompok kontrol terdapat 25 (73.5\%) responden di berikan MP-ASI. Kelompok kasus 14 (82.4\%) responden melakukan pola asuh yang kurang baik dan kelompok kontrol terdapat $26(76.6 \%)$ responden melakukan pola asuh yang baik.

Tabel 1. Distribusi frekuensi Konsumsi Tablet FE, BB bayi baru lahir, IMD, Asi Eksklusif, MPASI, Pola Asuh, dengan kejadian stunting di Puskesmas Sitiung I tahun 2021

\begin{tabular}{|c|c|c|c|c|}
\hline \multirow[t]{2}{*}{ Variabel } & \multicolumn{2}{|c|}{ case } & \multicolumn{2}{|c|}{ control } \\
\hline & $f$ & $\%$ & $f$ & $\%$ \\
\hline \multicolumn{5}{|c|}{ Konsumsi Tablet FE } \\
\hline Anemia & 12 & 70.6 & 8 & 23.5 \\
\hline Tidak anemia & 5 & 29.4 & 26 & 76.5 \\
\hline Total & 17 & 100 & 34 & 100 \\
\hline \multicolumn{5}{|l|}{ BB Bayi baru lahir } \\
\hline$<2500 \mathrm{gr}$ & 0 & 0 & 0 & 0 \\
\hline$\geq 2500 \mathrm{gr}$ & 17 & 100 & 34 & 97.1 \\
\hline Total & 17 & 100 & 34 & 100 \\
\hline \multicolumn{5}{|l|}{ IMD } \\
\hline Tidak & 10 & 58.8 & 14 & 41.2 \\
\hline lya & 7 & 41.2 & 20 & 58.8 \\
\hline Total & 17 & 100 & 34 & 100 \\
\hline \multicolumn{5}{|l|}{ Asi Eksklusif } \\
\hline Tidak & 11 & 64.7 & 9 & 26.5 \\
\hline lya & 6 & 35.3 & 25 & 73.5 \\
\hline Total & 17 & 100 & 34 & 100 \\
\hline \multicolumn{5}{|l|}{ MP-ASI } \\
\hline Tidak & 11 & 64.7 & 9 & 26.5 \\
\hline lya & 6 & 35.3 & 25 & 73.5 \\
\hline Total & 17 & 100 & 34 & 100 \\
\hline \multicolumn{5}{|l|}{ Pola asuh } \\
\hline Kurang baik & 14 & 82.4 & 8 & 23.5 \\
\hline Baik & 3 & 17.6 & 26 & 76.6 \\
\hline Total & 17 & 100 & 34 & 100 \\
\hline
\end{tabular}


Tabel 2 menunjukkan responden yang mengalami anemia sebanyak 20 , diantaranya 12 (70.6\%) pada kelompok kasus dan 8 (23.5\%) pada kelompok kontrol, sedangkan dari 31 responden yang tidak mengalami anemia sebanyak 5 (29.4\%) pada kelompok kasus, dan 26 (76.5\%) pada kelompok kontrol. Nilai $p \_v a l u e ~ 0.003$ (hubungan yang bermakna antara konsumsi tablet FE terhadap kejadian stunting di Puskesmas Sitiung I) dengan nilai OR 7.800.

Anak yang lahir dengan tidak dengan kondisi BBLR sebanyak 17 (100\%) pada kelompok kasus dan 34 (100\%) pada kelompok kontrol. Responden yang tidak melakukan IMD sebanyak 24 responden, diantaranya $10(58.8 \%)$ pada kelompok kasus dan 14 (41.2\%) pada kelompok kontrol, sedangkan dari 27 responden yang melakukan IMD sebanyak 7 (41.2\%) pada kelompok kasus dan 20 (58.8\%) pada kelompok kontrol. Nilai p_value 0.372 sehingga dapat disimpulkan tidak ada hubungan yang bermakna antara IMD terhadap kejadian stunting.

Responden tidak memberikan ASI Eksklusif sebanyak 20 responden, diantaranya 11 (64.7\%) pada kelompok kasus dan 9 (26.5\%) pada kelompok kontrol, sedangkan dari 31 responden yang memberikan ASI Eksklusif sebanyak 6 (35.3\%) pada kelompok kasus dan 25 (73.5\%) pada kelompok kontrol. Nilai $p \_v a l u e ~ 0.020$ (hubungan yang bermakna antara ASI Eksklusif terhadap kejadian stunting di Puskesmas Sitiung I) dengan nilai OR 5.093.

Tabel 2. Hubungan Konsumsi Tablet FE, BB bayi baru lahir, IMD, Asi Eksklusif, MP-ASI, Pola Asuh, dengan kejadian stunting di Puskesmas Sitiung I tahun 2021

\begin{tabular}{|c|c|c|c|c|c|c|c|}
\hline \multirow{3}{*}{ Variabel } & \multicolumn{7}{|c|}{ Puskesmas Sitiung I } \\
\hline & \multicolumn{2}{|c|}{ Case } & \multicolumn{2}{|c|}{ Control } & \multicolumn{2}{|c|}{ Jumlah } & \multirow{2}{*}{ P_value } \\
\hline & $f$ & $\%$ & $f$ & $\%$ & $f$ & $\%$ & \\
\hline \multicolumn{8}{|c|}{ Konsumsi Tablet FE } \\
\hline Anemia & 12 & 70.6 & 8 & 23.5 & 20 & 39.2 & \\
\hline Tidak anemia & 5 & 29.4 & 26 & 76.5 & 31 & 60.8 & 0.003 \\
\hline Total & 17 & 100 & 34 & 100 & 51 & 100 & \\
\hline \multicolumn{8}{|c|}{ BB Bayi baru lahir } \\
\hline$<2500 \mathrm{gr}$ & 0 & 0 & 0 & 0 & 0 & 0 & \\
\hline$\geq 2500 \mathrm{gr}$ & 17 & 100 & 34 & 97.1 & 51 & 100 & - \\
\hline Total & 17 & 100 & 34 & 100 & 51 & 100 & \\
\hline \multicolumn{8}{|l|}{ IMD } \\
\hline Tidak & 10 & 58.8 & 14 & 41.2 & 24 & 47.1 & \\
\hline lya & 7 & 41.2 & 20 & 58.8 & 27 & 52.9 & 0.372 \\
\hline Total & 17 & 100 & 34 & 100 & 51 & 100 & \\
\hline \multicolumn{8}{|l|}{ ASI Eksklusif } \\
\hline Tidak & 11 & 64.7 & 9 & 26.5 & 20 & 39.2 & \\
\hline lya & 6 & 35.3 & 25 & 73.5 & 31 & 60.8 & 0.020 \\
\hline Total & 17 & 100 & 34 & 100 & 51 & 100 & \\
\hline \multicolumn{8}{|l|}{ MP-ASI } \\
\hline Tidak & 11 & 64.7 & 9 & 26.5 & 20 & 39.2 & \\
\hline lya & 6 & 35.3 & 25 & 73.5 & 31 & 60.8 & 0.020 \\
\hline Total & 17 & 100 & 34 & 100 & 51 & 100 & \\
\hline \multicolumn{8}{|l|}{ Pola asuh } \\
\hline Kurang baik & 14 & 82.4 & 8 & 23.5 & 22 & 43.1 & \\
\hline Baik & 3 & 17.6 & 26 & 76.6 & 29 & 56.9 & 0.000 \\
\hline Total & 17 & 100 & 34 & 100 & 51 & 100 & \\
\hline
\end{tabular}


Responden yang tidak memberikan MP-ASI sebanyak 20 responden, diantaranya 11 (64.7\%) pada kelompok kasus dan 9 (26.5\%) pada kelompok kontrol, sedangkan dari 31 responden yang memberikan MP-ASI sebanyak 6 (35.3\%) pada kelompok kasus dan 25 (73.5\%) pada kelompok kontrol. Nilai pvalue 0.020 (ada hubungan yang bermakna antara MP-ASI terhadap kejadian stunting di Puskesmas Sitiung I) dengan nilai OR 5.093.

Responden yang melakukan pola asuh yang kurang baik sebanyak 22 responden, diantaranya 14 (82.4\%) pada kelompok kasus dan 8 (23.5\%) pada kelompok kontrol, sedangkan dari 29 responden yang melakukan pola asuh dengan baik sebanyak $3(17.6 \%)$ pada kelompok kasus dan 26 (76.6\%) pada kelompok kontrol. Nilai pvalue 0.000 (ada hubungan yang bermakna antara pola asuh terhadap kejadian stunting di Puskesmas Sitiung I) dengan nilai OR 15.16

\section{PEMBAHASAN}

Berdasarkan hasil penelitian pada kelompok kasus terdapat 12 (70.6\%) responden yang mengalami anemia sedangkan pada kelompok kontrol terdapat 26 (76.5\%) responden yang tidak mengalami anemia. Konsumsi 90 tablet selama kehamilan dapat mencegah terjadinya risiko anemia. Selain itu, untuk mendeteksi terjadinya anemia sejak dini pada ibu hamil maka dilakukan tes kadar hemoglobin. Zat besi merupakan mineral mikro vital yang dibutuhkan untuk pertumbuhan dan perkembangan janin. Zat besi berperan dalam perkembangan syaraf selama janin dan sebelum masa kanakkanak. Kebutuhan zat besi selama kehamilan meningkat menjadi $27 \mathrm{mg} / \mathrm{hari}$ khususnya pada kehamilan trimester kedua dan ketiga. Pemenuhan zat besi selama kehamilan dapat diperoleh dari cadangan besi, akan tetapi jika cadangan ini sedikit dan kandungan serta penyerapan zat besi dari diet sedikit maka diperlukan suplementasi zat besi (Menteri koordinator bidang kesejahteraan rakyat, 2013).
Berdasarkan penelitian yang telah dilakukan oleh (Nurmasari \& Sumarmi, 2019) dengan judul hubungan keteraturan kunjungan ANC dan kepatuhan konsumsi tablet FE dengan kejadian Anemia pada ibu hamil dikecamatan maron probolinggo bahwa ibu hamil yang tidak teratur melakukan ANC dan tidak patuh mengonsumsi tablet $\mathrm{Fe}$ sebesar 46,67\% mengalami anemia, sedangkan ibu hamil yang tidak teratur ANC akan tetapi patuh mengonsumsi tablet $\mathrm{Fe}$ sebesar 33,33\% mengalami anemia.

Menurut asumsi peneliti masih ada ibu hamil yang tidak lengkap mengkonsumsi tablet FE. Hal itu terjadi dikarenakan konsep mengenai betapa pentingnya konsumsi tablet FE belum di ketahui oleh ibu dengan baik, padahal kebutuhan zat besi selama kehamilan meningkat menjadi $27 \mathrm{mg} / \mathrm{hari}$. Banyak diantaranya ibu hamil yang tidak mengkonsumsi tablet fe karena Mual, lupa, dan malas mengkonsumsi. Ini tugas dari tenaga kesehatan untuk memberikan informasi kepada ibu hamil mengenai manfaat dan tujuan dari mengkonsumsi tablet FE selama kehamilan. Dampak yang ditimbulkan akibat anemia saat kehamilan adalah perdarahan pasca melahirkan dan berat bayi lahir rendah. Anemia yang terjadi pada ibu hamil akan berpengaruh pada fungsi imunitas tubuh. Infeksi pada ibu hamil akan meningkatkan risiko terjadinya kelahiran bayi premature.

Di Puskesmas Sitiung I pada kelompok kasus terdapat 17 (100\%) responden lahir tidak dengan kondisi BBLR sedangkan pada kelompok kontrol terdapat 34 (100\%) responden lahir tidak dengan kondisi BBLR. Menurut penelitian (Illahi, 2017) dengan judul Hubungan Pendapatan Keluarga, Berat Lahir, Dan Panjang Lahir Dengan Kejadian Stunting Balita 24-59 Bulan Di Bangkalan diketahui bahwa proporsi balita stunting lebih banyak terdapat pada balita dengan berat badan lahir rendah yaitu sebesar $75 \%$, sedangkan pada balita dengan berat badan lahir normal terdapat $25,9 \%$ balita yang mengalami stunting. 
Menurut asumsi peneliti kondisi anak yang lahir < 2500gr itu sangat mempengaruhi tumbuh kembang anak di masa yang akan datang. Anak yang lahir dengan kondisi BBLR ini di pengaruhi olah faktor ibu, misalnya ibu hamil dengan anemia, hamil di usia muda, dan ibu KEK. Dari hasil penelitian mayoritas balita di lahirkan dengan kondisi normal dengan berat lahir $\geq 2500 \mathrm{gr}$, walaupun begitu peran tenaga kesehatan di sini juga sangat dibutuhkan untuk memberikan informasi yang kepada ibu mengenai gizi pada ibu hamil, pola makan ibu hamil agar bayi di lahirkan sehat tanpa kekurangan apapun.

Di Puskesmas Sitiung I pada kelompok kasus terdapat 10 (58.8\%) responden tidak melakukan IMD sedangkan pada kelompok kontrol terdapat 20 (58.8\%) responden yang melakukan IMD. Inisiasi Menyusui Dini ( IMD ) adalah proses yang dimulai secepatnya. IMD dilakukan dengan cara membiarkan bayi kontak kulit dengan kulit ibunya setidaknya selama satu jam pertama setelah lahir atau hingga proses menyusu awal berakhir (Sandra, Ahmad, \& Khaula, 2015).

Penelitian (Hafid \& Nasrul, 2017) menyebutkan frekuensi yang tidak melakukan IMD 207 (59.1\%) yang melakukan IMD 143 (40.9\%). Inisiasi menyusui dini (IMD) adalah proses bayi menyusui segera setelah dilahirkan. IMD ini sangat bermanfaat untuk membantu meningkatkan daya tahan tubuh pada bayi selain itu kedekatan antara ibu dengan bayi akan terbentuk dalam proses inisiasi menyusui dini. IMD ini di lakukan diharapakan bayi mendapatkan kolostrum, karena didalam kolostrum sangat kaya protein dan nutrisi dan termasuk antibody untuk melindungi bayi dari infeksi. Dari hasil penelitian yang telah di lakukan pada kelompok kasus banyak balita yang tidak IMD, ini di sebabkan dari berbagai faktor misalnya anak yang lahir dengan proses operasi dan dengan penyulit lainnya.

Di Puskesmas Sitiung I pada kelompok kasus terdapat 11 (64.7\%) responden tidak diberikan ASI Eksklusif sedangkan pada kelompok kontrol terdapat 25 (73.5\%) responden di berikan ASI Eksklusif. Usia ibu yang terlalu muda atau terlalu tua pada saat hamil dapat berpengaruh terhadap keberadaan kehamilannya. Seorang ibu hamil dikategorikan terlalu muda hamil jika pada saat hamil usianya kurang dari 20 tahun dan dikategorikan terlalu tua hamil jika usianya pada saat hamil lebih dari 35 tahun (Ayu, Wayan, Tri, Widhi, \& Gunapria, 2017).

Asi eksklusif adalah air susu ibu yang wajib diberikan atau di susukan pada bayinya yang baru lahir sampai bayinya berusia 6 bulan, tanpa diberikan tambahan apapun pada bayi tersebut. Dimana selama memberikan ASI eksklusif, ibu tidak perlu memberika tambahan apapun untuk bayi, baik air putih, sari buah buah Maupun susu formula. Selama 6 bulan pertama bayi benar - benar hanya mendapatkan air sus ibu saja. Air susu ibu yang dberikan secara eksklusif tersebut terutama banyak mengandung zat gizi yang sangat bermanfaat buat bayi karena kurang lebih di hari 1-3 air susu ibu mengandung kolostrum. Kolostrum sangat bermanfaat untuk bayi (Widuri Hesti, 2013)

Menurut asumsi peneliti ASI Eksklusif itu sangat perlu diberikan kepada bayi selama 6 bulan tanpa di berikan makanan tambahan apapun Karen sangat banyak kandungan zat gizi di dalam ASI. Air susu ibu ini bermanfaat untuk menambah kekebalan tubuh terhadap penyakit infeksi pada balita. Dari hasil penelitian yang telah dilakukan mayoritas responden pada kelompok kasus banyak yang tidak memberikan ASI Eksklusif yang disebabkan dari berbagai faktor diantaranya masih banyak orang tua yang beranggapan jika bayi masih menangis setelah menyusui berarti si bayi masih lapar jadi disana orang tua berfikiran untuk memberikan makanan tambahan secara dini kepada si bayi, ada juga sebagian ibu yang sejak bayi lahir Asi nya yang tidak keluar, faktor pendidikan dan pengetahuan juga mempengaruhi proses pemberian Asi Ekslusif.

Puskesmas Sitiung I pada kelompok kasus terdapat 11 (64.7\%) responden tidak di berikan MP-ASI sedangkan pada kelompok 
kontrol terdapat 25 (73.5\%) responden di berikan MP-ASI. MP-ASI adalah memberikan makanan lain pada bayi disamping memberikan ASI. Pemberian MP-ASI tersebut diberikan secara bertahap sampai bayi bisa mengkonsumsi makanan dewasa/keluarga. Pemberian MP-ASI dengan makanan keluarga biasanya diberikan setelah bayi berusia 12 bulan. ASI seluruhnya diganti dengan makanan keluarga. MP-ASI sudah dapat diberikan pada saat bayi berusia 6 bulan. Pada saat itu bayi bisa mendapatkan makanan yang lunak, atau makanan yang dihaluskan karena bayi sudah dapat mengendalikan lidahnya dengan baik mulai dapat mengunyah (gerakan lidah keatas dan ke bawah), bayi suka menaruh makanan di mulutnya, dan bayi sudah menyukai rasa makanan lain (gurih, manis, segar, DIl).(Widuri Hesti, 2013).

Berdasarkan penelitian (Aridiyah, Rohmawati, \& Ririanty, 2015) dengan judul Faktor Faktor Yang Mempengaruhi Kejadian Stunting Pada Anak Balita Diwilayah Pedesaan Dan Perkotaan, Pada umur pemberian MP-ASI pertama kali pada anak balita stunting yang berada di desa sebagian besar adalah pada umur $\leq 6$ bulan sebanyak $64,5 \%$, sedangkan untuk di wilayah perkotaan sebagian pada umur > 6 bulan dengan persentase 60\%. Pemberian makanan pendamping ASI secara tepat waktu yaitu di usia 6 bulan itu sangat penting karena jika MPASI diberikan terlalu dini itu akan mengganggu kesehatan bayi karena kondisi pencernaannya belum siap dan jika diberikan terlalu terlambat bisa jadi nanti bayi susah menerima makanan selain ASI. Dari hasil penelitian yang telah dilakukan mayoritas ibu ibu tidak tepat waktu dalam memberikan MPASI. ibu yang memberikan makanan tambahan di usia dini seperi pemberian buahbuahan kepada bayi. Dari hasil wawancara yang telah dilakukan banyak ibu ibu yang kurang mengerti mengenai waktu yang tepat dalam pemberian MPASI ini disebabkan dari faktor pendidikan dan pengetahuan ibu. Disini sangat diperlukan peran dari petugas kesehatan dalam memberikan informasi yang jelas mengenai jadwal pemberian MP-ASI, menu yang baik dalam pemberian MP-ASI. Hendaknya ibu-ibu juga memperhatikan bagaimana tekstrus dari MP-ASI karna itu sangat mempengaruhi pencernaan bayi.

Di Puskesmas Sitiung I pada kelompok kasus terdapat 14 (82.4\%) responden melakukan pola asuh yang kurang baik sedangkan pada kelompok kontrol terdapat 26 (76.6\%) responden melakukan pola asuh yang baik. Berdasarkan penelitian yang dilakukan oleh (Widyaningsih et al., 2018) Dengan Judul Keragaman Pangan, Pola Asuh Makan Dan Kejadian Stunting Pada Balita Usia 24-59 Bulan persentase balita stunting yang mempunyai pola asuh makan kurang (51,2\%) lebih banyak jika dibandingkan dengan balita stunting yang mempunyai pola makan yang baik $(48,8 \%)$. Pada tahun pertama kehidupan, hubungan yang erat, mesra dan selaras antara ibu/pengganti ibu dengan anak merupakan syarat mutlak untuk menjamin tumbuh kembang yang selaras baik fisik, mental maupun psikososial. Berperanya dan kehadiran ibul penggantinya sendiri dan selanggeng mungkin, akan menjalin rasa aman bagi bayinya. Ini diwujudkan dengan kontak fisik (kulit/mata) dan psikis sedini mungkin, misalnya dengan menyususi bayi secepat mungkin segera setelah lahir. Kekurangan kasih sayang ibu pada tahuntahun pertama kehidupan mempunyai dampak negatif pada tumbuh kembang anak, baik fisik, mental maupun sosial emosi yang disebut sindrom deprivasi maternal. Kasih sayang dari orang tuanya (ayah-ibu) akan menciptakan ikatan yang erat (bonding) dan kepercayaan dasar (basic trust) sebagainya (Soetjiningsih, 2012).

Berdasarkan penelitian yang dilakukan oleh (Rahman, Farah Danita., 2018) dengan judul Pengaruh Pola Pemberian Makanan Terhadap Kejadian Stunting Pada Balita Studi Di Wilayah Kerja Puskesmas Kabupaten Jember. Yang melakukan pola asuh kurang baik pada kelompok stunting sebesar 53 
(67.1\%) dan pola asuh yng baik sebesar 18 (28.6\%). Pola asuh yang baik menentukan tumbuh kembang balita. Setiap orang tua memiliki gaya atau pola suh yang berbedabeda. Perbedaan pola asuh ini dampaknya pun juga berbeda terhadap perkembangan dan pembentukan karakter anak. Namun tanpa di sadar masih banyak orang tua yang memberikan pola asuh yang salah hal tersebut bisa di sebabkan oleh faktor pengetahuan dan pendidikan orang tua yang rendah. Asah, asih dan asuh itu harus seimbang agar kedekatan anak dan orang tua mempunyai hubungan yang erat. Dari hasil penelitian yang telah di lakukan masih banyak responden yang melakukan pola asuh yang kurang baik. Dalam hal ini masih sangat di butuhkan peran dari tenaga kesehatan untuk memberikan informasi yang jelas mengenai pola asuh yang baik agar orang tua dapat menambah ilmu pengetahuannya dan mengubah cara pola asuh.

Dapat diketahui dari 51 responden, yang mengalami anemia sebanyak 20, diantaranya 12 (70.6\%) pada kelompok kasus dan 8 (23.5\%) pada kelompok kontrol, sedangkan dari 31 responden yang tidak mengalami anemia sebanyak 5 (29.4\%) pada kelompok kasus, dan 26 (76.5\%) pada kelompok kontrol. hasil uji statistik di peroleh nilai $p \_$value 0.003 maka dapat disimpulkan bahwa ada hubungan yang bermakna antara konsumsi tablet FE terhadap kejadian stunting di Puskesmas Sitiung I. Jumlah zat besi yang dibutuhkan untuk kehamilan adalah sekitar $1.000 \mathrm{mg}$, 350mg untuk pertumbuhan janin dan plasenta, $450 \mathrm{mg}$ untuk peningkatan massa sel darah merah ibu, dan 240mg untuk kehilangan basal. Zat besi adalah salah satu nutrient yang tidak dpat diperoleh dalam jumlah yang adekuat dalam makanan. Tambahan zat besi dalam bentuk garam ferrous dengan dosis $30 \mathrm{mg}$ per hari, dimulai sejak kunjungan prenatal pertama guna mempertahankan cadangan ibu dalam memenuhi kebutuhan janin ( Mandriwati Gusti Ayu, 2017).
Berdasarkan penelitian yang dilakukan oleh (Syafa'ah, 2016) dengan judul Hubungan Status Gizi Dan Asupan Gizi Ibu Hamil Trimester III Dengan Panjang Bayi Lahir Di Puskesmas Bendosari Kabupaten Sukoharjo Hasil uji statistik variabel asupan Fe dengan panjang bayi lahir diperoleh $p=0,000, r=0,567$. Menurut asumsi peneliti konsumsi tablet FE yang lengkap pada selama kehamilan itu penting karena tablet FE merupakan salah satu zat gizi yang sangat dibutuhkan oleh ibu hamil. dapat mencegah terjadinya anemia dan menambah asupan nutrisi pada janin. Jika ibu anemia dapat membuat ibu hamil lemas dan kelelahan dan system kekebalan tubuh menjadi lemah sehingga ibu bisa rentan untuk terkena penyakit infeksi dan dapat menimbulkan resiko pada bayi. Dari hasil peneltian yang telah di lakukan konsumsi tablet FE itu sangat berpengaruh pada kejadian stunting. banyak dari ibu ibu yang malas dan lupa mengkonsumsi tablet $\mathrm{FE}$, sehubungan dengan kunjungan ANC yang tidak lengkap maka berpengaruh juga dengan jumlah konsumsi tablet FE.

Dapat diketahui dari 51 responden, anak yang lahir dengan BBLR sebanyak 0 responden, sedangkan dari 51 responden lahir tidak dengan kondisi BBLR sebanyak 17 (100\%) pada kelompok kasus dan 34 (100\%) pada kelompok kontrol. Salah satu faktor risiko yang mempengaruhi kejadian stunting pada anak balita adalah riwayat berat badan lahir rendah (BBLR) (4). Akibatnya pertumbuhan bayi BBLR akan terganggu, bila keadaan ini berlanjut dengan pemberian makanan yang tidak mencukupi,sering mengalami infeksi, dan perawatan kesehatan yang tidak baik dapat menyebabkan anak stunting ( Nasution, Darwin, 2014 ).

Berdasarkan penelitian yang dilakukan oleh Wiwien Fitrie Wellina dengan judul Faktor resiko stunting pada anak umur 12-24 bulan uji statistic dengan p_value 0.002 bahwa proposi baduta dengan berat badan lahir rendah lebih cenderung menjadi stunting yaitu sebesar 3,63 kali dibandingkan dengan baduta yang berat badan lahirnya normal. 
Berdasarkan penelitian yang dilakukan oleh Fahmi Hafid dan Nasrul dengan judul Faktor Resiko Stunting Pada Anak Usia 6-23 bulan dikabupaten janeponto tahun 2016 Kejadian stunting memiliki hubungan yang signifikan dengan BBLR $(p<0,05)$. Bayi BBLR juga mengalami gangguan saluran pencernaan karena saluran pencernaan belum berfungsi seperti kurang dapat menyerap lemak dan mencerna protein sehingga mengakibatkan kurangnya cadangan zat gizi dalam tubuh. Akibatnya, pertumbuhan bayi BBLR akan terganggu dan apabila keadaan ini berlanjut dengan pemberian makanan yang tidak mencukupi, sering mengalami infeksi, dan perawatan kesehatan yang tidak baik, dapat menyebabkan anak mengalami stunting. ( Nasution,Darwin. 2014 ).

Berdasarkan penelitian yang dilakukan oleh Darwin Nasution Dkk dengan judul Berat Badan Lahir Rendah (BBLR) Dengan kejadian stunting pada anak usia 6-24 bulan asil analisis menunjukkan nilai OR=5,60 (95\% $\mathrm{Cl}$ : 2,27-15,70), artinya pada tingkat kepercayaan 95\% dapat disimpulkan bahwa anak yang lahir dengan BBLR mempunyai risiko 5,6 kali lebih besar untuk menjadi stunting dibandingkan dengan anak yang lahir dengan berat badan normal. Menurut asumsi peneliti BBLR itu mempengaruhi tumbuh kembang anak di masa yang akan datang. Anak dengan BBLR akan memiliki antropometri yang kurang dari perkembangannya dan mengalami hambatan pertumbuhan atau stunting. dari hasil penelitian yang telah di lakukan dari 4 kabupaten kota bahwa tidak ada hubungan BBLR terhadap kejadian stunting. bayi yang lahir dengan berat badan yang tidak normal disebabkan karena sang ibu ketika selama hamil memiliki pola makan yang kurang baik.

Dapat diketahui dari 51 responden, yang tidak melakukan IMD sebanyak 24 responden, diantaranya 10 (58.8\%) pada kelompok kasus dan 14 (41.2\%) pada kelompok kontrol, sedangkan dari 27 responden yang melakukan IMD sebanyak 7
(41.2\%) pada kelompok kasus dan 20 (58.8\%) pada kelompok kontrol. hasil uji statistik diperoleh nilai $p_{-}$value 0.372 maka dapat disimpulkan bahwa tidak ada hubungan yang bermakna antara IMD terhadap kejadian stunting di Puskesmas Sitiung I. Dalam mencapai tumbuh kembang Inisiasi Menyusui Dini ( IMD ) adalah proses yang dimulai secepatnya. IMD dilakukan dengan cara membiarkan bayi kontak kulit dengan kulit ibunya setidaknya selama satu jam pertama setelah lahir atau hingga proses menyusu awal berakhir. cara bayi melakukan IMD ini di namakan the breast crawl atau merangkak mencari payudara (Fikawati Sandra dkk, 2015).

Berdasarkan penelitian yang telah dilakukan oleh (Hafid \& Nasrul, 2017) dengan judul Faktor Risiko Stunting Ada Anak Usia 6-23 Bulan Di Kabupaten Jeneponto Tahun 2016. Di dapatkan hasil tidak ada hubungan IMD dengan kejadian stunting hasil uji statistic $p \_$value 0.405 . Menurut asumsi peneliti inisiasi menyusui dini (IMD) merupakan faktor pencegah kejadian stunting pada balita. Salah satu hal yang jadi kunci keberhasilan proses menyusui adalah dilaksanakannya IMD segera mungkin setelah persalinan. IMD dilakukan untuk meningkatkan kesempatan bayi memperoleh kolostrum, karena didalam kolostrum sangat banyak protein dan gizi yang dapat meningkatkan kekebalan tubuh. Sangat rugi seorang ibu jika tidak melakukan IMD kepada anak nya. mayoritas pada kelompok kasus responden tidak diberikan IMD yang disebabkan dari bermacam faktor misalnya pasien yang bersalin dengan proses operasi dan ada juga tenaga kesehatan yang tidak melakukan IMD.

Dapat diketahui dari 51 responden, yang tidak memberikan ASI Eksklusif sebanyak 20 responden, diantaranya 11 (64.7\%) pada kelompok kasus dan 9 (26.5\%) pada kelompok kontrol, sedangkan dari 31 responden yang memberikan ASI Eksklusif sebanyak 6 (35.3\%) pada kelompok kasus dan 25 (73.5\%) pada kelompok kontrol. hasil 
uji statistik diperoleh nilai $p \_v a l u e ~ 0.020$ maka dapat disimpulkan bahwa ada hubungan yang bermakna antara ASI Eksklusif terhadap kejadian stunting di Puskesmas Sitiung I. Pemberian ASI selama 6 bulan adalah jangka waktu yang paling optimal untuk pemberian ASI eksklusif (Akerstro'm, 2007). Memperpanjang pemberian ASI eksklusif sampai usia bayi 6 bulan memberi berbagai manfaat bagi bayi, antara lain (1) menurunkan risiko gizi berlebih, (2) meningkatkan kesehatan di masa kanakkanak, (3) meningkatkan kekebalan tubuh, (4) menekan risiko alergi, bercak kulit, diare, infeksi saluran napas, (5) tidak membuat berat badan bayi turun (Rosita, Neng Ayu,2016).

Berdasarkan penelitian yang dilakukan oleh Thesale fikadu et al dengan judul FaktorFaktor Yang Terkait Dengan Pengerdilan Di Antara Anak-Anak Usia 24 Hingga 59 Bulan Di Distrik Meskan, Gurage Zone, South Ethiopia Anak-anak yang diberi ASI eksklusif selama $<6$ bulan $[A O R=3,27,95 \% \mathrm{Cl}: 1,21$, 8,82] lebih mungkin mengembangkan stunting dibandingkan anak-anak yang diberi ASI eksklusif selama 6 bulan pertama. Asi Eksklusif yang di berikan selama 6 bulan itu sangat penting, karena kandungan yang ada di dalam Asi sudah sesuai dengan kebutuhan bayi sehingga dapat memaksimalkan pertumbuhan bayi. Jika bayi tidak di berikan Asi eksklusif dengan cukup berarti bayi memiliki asupan gizi yang kurang, bayi kekurangan gizi salah satu penyebab terjadinya stunting.

Dapat diketahui dari 51 responden, yang tidak memberikan MP-ASI sebanyak 20 responden, diantaranya 11 (64.7\%) pada kelompok kasus dan 9 (26.5\%) pada kelompok kontrol, sedangkan dari 31 responden yang memberikan MP-ASI sebanyak 6 (35.3\%) pada kelompok kasus dan 25 (73.5\%) pada kelompok kontrol. hasil uji statistik diperoleh nilai pvalue 0.020 maka dapat disimpulkan bahwa ada hubungan yang bermakna antara MP-ASI terhadap kejadian stunting di Puskesmas Sitiung I. Dalam mencapai tumbuh kembang optimal, di dalam Global Strategy for Infant and Young Child Feeding, WHO/UNICEF merekomen-dasikan empat hal penting yang harus dilakukan yaitu : pertama memberikan Air Susu Ibu kepada bayi segera dalam 30 menit setelah bayi lahir, kedua memberikan hanya Air Susu Ibu (ASI) saja atau pemberian ASI secara Eksklusif sejak lahir sampai bayi berusia 6 bulan, ketiga memberikan Makanan Pendamping Air Susu Ibu (MP-ASI) sejak bayi berusia 6 bulan sampai 24 bulan, dan keempat meneruskan pemberian ASI sampai anak berusia 24 bulan atau lebih2. Hal tersebut menekankan, secara sosial budaya MP-ASI hendaknya dibuat dari bahan yang murah dan mudah diperoleh dari daerah setempat (indegenous food) (Agus Hendra, 2013).

Hasil penelitian ini sejalan dengan penelitian yang dilakukan oleh (Agus Hendra, 2013) dengan judul kajian stunting pada anak balita ditinjau dari pemeberian Asi Eksklusif, MP-ASI, Status imunisasi dan karakteristik Keluaraga Di kota Banda Aceh Hasil uji statistik diperoleh nilai $p=0,007(p<0,05)$ sehingga Ho ditolak dan Ha diterima, hal ini berarti bahwa kejadian stunting pada anak balita di Kota Banda Aceh tahun 2010 disebabkan oleh pemberian MP-ASI yang kurang baik. Nilai OR 3,4 (Cl 95\%; 1,5 - 7,9). Hasil penelitian ini sejalan penelitian yang dilakukan oleh (Najahah et al., 2013) dengan judul Faktor risiko balita stunting usia 12-36 bulan di Puskesmas Dasan Agung, Mataram, Provinsi Nusa Tenggara Barat bahwa MPASI dari uji statistik diperoleh nilai $p_{-}$value 0.000 dengan nilai OR 6.38 .

Berdasarkan penelitian (Meilyasari, Friska, 2014) dengan judul Faktor Risiko Kejadian Stunting Pada Balita Usia 12 Bulan Di Desa Purwokerto Kecamatan Patebon, Kabupaten Kendal Didapatkan MP-ASI $(O R=1,41 ; P=0,77)$ Bukan Merupakan Faktor Risiko Kejadian Stunting. MP-ASI yang tepat waktu di berikan itu sangat berpengaruh terhadap tumbuh kembang anak, karena jika MP-ASI terlalu dini diberikan itu akan mempengaruhi kepada system 
pencernaannya, karena anak yang berusia di bawah 6 bulan memiliki system pencernaan yang kurang baik. Pengenalan MP-ASI itu juga mampu mendukung perkembangan pengindraan mulai dari pengecapan, peraba dan pencium sang anak. Di sini peran sang ibu sangat berpengaruh terhadap pemberian MP-ASI, pemilihan menu dan tekstur dari MPASI juga sangat penting untuk di fikirkan. Dari hasil penelitian yang telah dilakukan melalui uji bivariate bahwa pemberian MP-ASI juga berhubungan dengan kejadian stunting. dari hasil wawancara yang telah dilakukan bahwa banyak sang ibu yang salah pilih menu untuk pemberian MP-ASI kepada anak, dan tekstur yang kurang halus. Perlunya pendidikan yang di berikan tenaga kesehatan kepada ibu untuk menambah informasi yang lebih jelas mengenai manfaat dan cara pemberian MPASI kepada sang anak.

Dapat diketahui dari 51 responden, melakukan pola asuh yang kurang baik sebanyak 22 responden, diantaranya 14 (82.4\%) pada kelompok kasus dan 8 (23.5\%) pada kelompok kontrol, sedangkan dari 29 responden yang melakukan pola asuh dengan baik sebanyak $3(17.6 \%)$ pada kelompok kasus dan 26 (76.6\%) pada kelompok kontrol. hasil uji statistik diperoleh nilai pvalue 0.000 maka dapat disimpulkan bahwa ada hubungan yang bermakna antara pola asuh terhadap kejadian stunting di Puskesmas Sitiung I. Salah satu penyebab tidak langsung kejadian stunting adalah pola asuh. Pola pengasuhan secara tidak langsung akan mempengaruhi status gizi anak. Pengasuhan dimanifestasikan dalam beberapa aktivitas yang biasanya dilakukan oleh ibu seperti praktek pemberian makan anak, praktek sanitasi dan perawatan kesehatan anak. Beberapa penelitian menunjukkan bahwa pola asuh merupakan faktor risiko kejadian stunting pada anak (Niga, Desiansi Merlinda. Tahun 2016).

Berdasarkan penelitian yang dilakukan oleh (Rahmayana, Irviani A. Ibrahim, 2016) Hubungan Pola Asuh Ibu Dengan Kejadian Stunting Anak Usia 24-59 Bulan Di Posyandu
Asoka II Wilayah Pesisir Kelurahan Barombong Kecamatan Tamalate Kota Makassar Tahun 2014 menunjukkan adanya hubungan yang signifikan antara praktik pemberian makan $(P=0,007)$, rangsangan psikososial $(P=0,000)$. Berdasarkan penelitian yang dilakukan oleh (Rahman, Farah Danita., 2018) dengan judul Pengaruh Pola Pemberian Makanan Terhadap Kejadian Stunting Pada Balita Studi Di Wilayah Kerja Puskesmas Kabupaten Jember didapatkan hasil uji statistic menunjukkan bahwa terdapat pengaruh pola asuh pemberian makan terhadap kejadian stunting dengan $p_{-}$value 0.000 . Pola asuh merupakan proses interaksi antara si kecil dengan orang tua meliputi memenuhi kebutuhan fisik dan kebutuhan psikologi anak. Menurut hasil penelitian dari 4 kabupaten kota hanya di pasaman barat tidak adanya hubungan pola asuh terhadap kejadian stunting. dari hasil wawancara yang telah dilakukan masih banyak orang tua yang tidak memberikan pola asuh yang baik itu di karenakan dari berbagai faktor misalnya pendidikan ibu, semakin tinggi pendidikan ibu maka semakin banyak juga informasi yang ibu terima dan penyerapannya berbeda. Pertumbuhan dan perkembangan anak seharusnya sangat di perhatikan dan di jaga dengan baik, dan sang ibu juga harus jeli memperhatikan tumbuh kembang si anak teruatama pada masa golden age. Untuk mengoptimalkan perkembangan anak hendaknya kedua orang tua harus berperan penting di dalam membantu tubuh kembang anak, terutama sang ibu.

\section{KESIMPULAN}

Berdasarkan penelitian yang telah dilakukan di Puskesmas Sitiung I variabel yang berhubungan dengan kejadian stunting yaitu Konsumsi Tablet FE, ASI Eksklusif, MP-ASI, dan pola asuh. Dalam penulisan Jurnal ini dari awal sampai akhir tidak terlepas dari peran berbagai pihak yaitu kepada kepala puskesmas, bidan desa, kader. Penulis mengucapkan terima kasih kepada pihakpihak yang sudah banyak membantu. 


\section{REFERENSI}

BAPPENAS. (2012). SUN Movement Gerakan Nasional 1 . 000 Hari Pertama Kehidupan (pp.1-2).

Kementrian Kesehatan RI. (2011). Standar Antropometri Penilaian Status Gizi Anak (pp.4-41)

Kemenkes RI. (2017). Profil Kesehatan Indonesia. Unicef. (2016). The State of The World'S Children.https://doi.org/10.1016/0167 577X(84)90080-6

Riskesdas. (2018). Kementrian Kesehatan Republik Indonesia.

Fikadu, T., Assegid, S., \& Dube, L. (2014). Factors associated with stunting among children of age 24 to 59 months in Meskan district, Gurage Zone, South Ethiopia : a case-control study, 1-7.

Geberselassie, S. B., Abebe, S. M., Melsew, Y. A., Mutuku, S. M., \& Wassie,M.M. (2018). Prevalence of stunting and its associated factors among children 6-59 months of age in Libo-Kemekem district, Northwest Ethiopia; A community based cross sectional study. PLOS ONE,13(5), 1-12.

https://doi.org/10.1371/journal.pone.0195 361

Kementerian Desa Pembangunan Daerah Tertinggal dan Transmigrasi. (2018). Buku saku desa dalam penanganan stunting.

Sukarni Icesmi, S. (2014). Patologi Kehamilan, Persalinan, Nifas, Dan Neonatus Resiko Tinggi. Yogyakarta: Nuha Medika.

Sandra, F., Ahmad, S., \& Khaula, K. (2015). gizi ibu dan bayi. Jakarta: PT Raja Grafindo Persada.

Widuri Hesti. (2013). Cara Mengelola Asi Eksklusif Bagi Ibu Bekerja. Yogyakarta: Gosyen Publishing.

Mahayu Puri. (2016). Perawatan Bayi dan Balita. Yogyakarta: Saufa.

Soetjiningsih. (2012). tumbuh kembang anak.pdf. Jakarta: Buku Kedokteran EGC.

Par'i Holil Muhammad. (2017). penilaian status gizi. Jakarta: Buku Kedokteran EGC.
Latifah. Noor. (2012). Kehamilan Dengan Kejadian Kematian Neonatal ( Analisis Data Sdki 2007 ) Tesis.

Nurmasari, V., \& Sumarmi, S. (2019). Hubungan Keteraturan Kunjungan Anc (Antenatal Care) Dan Kepatuhan Konsumsi Tablet Fe Dengan Kejadian Anemia Pada Ibu Hamil Trimester III Di Kecamatan Maron Probolinggo. Amerta Nutrition, 3(1), 46. https://doi.org/10.20473/amnt.v3i1.2019. 46-51

Priyono, D.I.P, Sulistiyani, R. L. . (2015). Determinan Kejadian Stunting pada Anak Balita Usia 12-36 Bulan di Wilayah Kerja Puskesmas Randuagung Kabupaten Lumajang (Determinants of Stunting among Children Aged 12-36 Months in Community Health Center of Randuagung, Lumajang Distric ). Jurnal Kesehatan Masyaakat, 3(2), 349-355.

Pratama, I. S., Aini, S. R., \& Maharani, B. F. (2019). Implementasi Gasing (Gerakan Anti Stunting) Melalui PHBS Dan Pemeriksaan Cacing. Jurnal Pendidikan Dan Pengabdian Masyarakat, 2(1), 8083.

Par'i Holil Muhammad. (2017). penilaian status gizi. Jakarta: Buku Kedokteran EGC.

Manuhutu, Rendy, Dyah Umiyarni Purnamasari, dan E. D. (n.d.). Status Kecacingan Terhadap Status Gizi Pada Siswa Sekolah Dasar Negeri 01 Limpakuwus, 46-55.

M.Ginting, Trisya, Evawany Y.Aritonang, A. S. (2013). Hubungan Jarak Kelahiran Dan Pola Pengasuhan Dengan Status Gizi Anak Balita Di Wilayah Kerja Puskesmas Kecamatan Tanjung Tiran Kabupaten Batu Bara, 1-110.

Mahayu Puri. (2016). Perawatan Bayi dan Balita. Yogyakarta: Saufa.

Mardalena Ida. (2017). dasar dasar ilmu gizi dalam keperawatan. Yogyakarta: Pustaka Baru Press.

Maryunani Anik. (2016). Perilaku Hidup Bersih Dan Sehat. Jakarta: Trans Info Media.

Menteri koordinator bidang kesejahteraan rakyat. (2013). Kerangka kebijakan 1000 HPK 